\title{
LOAD SPECTRUM OF A CAR POWERTRAIN
}

\section{JOSEF MORKUS}

ČVUT, Fakulta strojní, Technická 4, 16607 Prague 6

E-mail: josef.morkus@fs.cvut.cz

\section{SHRNUTí}

Motor vozidla pracuje během jízdy v různých bodech jeho charakteristiky v závislosti na měnících se požadavcích na jeho moment a otáčky. Zatižžení hnacího ústrojí mưže být popsáno prostřednictvím zátěžné mapy, nazývané spektrum zatižení. Článek popisuje různé formy spektra zatižení, metody jeho získání (přímé měření, simulace jízdy vozidla na počítači a zjednodušený smluvní výpočet), analyzuje jejich výhody a nevýhody a je ukázána aplikace spektra zatižení pro výpočty namáhání a životnosti součástí hnacího ústrojí. KLIICOOVÁ SLOVA: SPEKTRUM ZATIZŽENÍ, VYUŽITÍ PŘEVODOVÝCH STUPÑŮ, EKVIVALENTNÍ ZATİŽENÍ

\section{ABSTRACT}

When a car is driven, the engine works at different points of its characteristics, depending on fluctuating requirements for torque and revolutions. The powertrain load can be described by a load map, called a load spectrum. The article describes different forms of load spectrum, methods for obtaining it (direct measuring, computer simulation and simplified calculation), analyses of their advantages and disadvantages, and it presents the application of a load spectrum for powertrain stress and service life calculations.

\section{KEYWORDS: LOAD SPECTRUM, RELATIVE UTILIZATION OF PARTICULAR GEARS, EQUIVALENT LOAD}

\section{INTRODUCTION}

Knowledge of load is the basis for powertrain stress and life calculations, or for prediction of fuel consumption or emissions. The load can be described in different forms: by a time-based plot of load and revolutions, as a two-dimensional (torque and revolutions) spectrum, a one-dimensional (torque) spectrum or an equivalent load.

\section{WHAT IS A LOAD SPECTRUM}

When a car is driving, engine torque and revolutions are continuously changing depending on operating conditions and driver requirements. In parallel with this, the active gearbox gear must be also changed to achieve the required torque at the car wheels. An example of a torque and revolutions time based graph is shown in Figure 1.
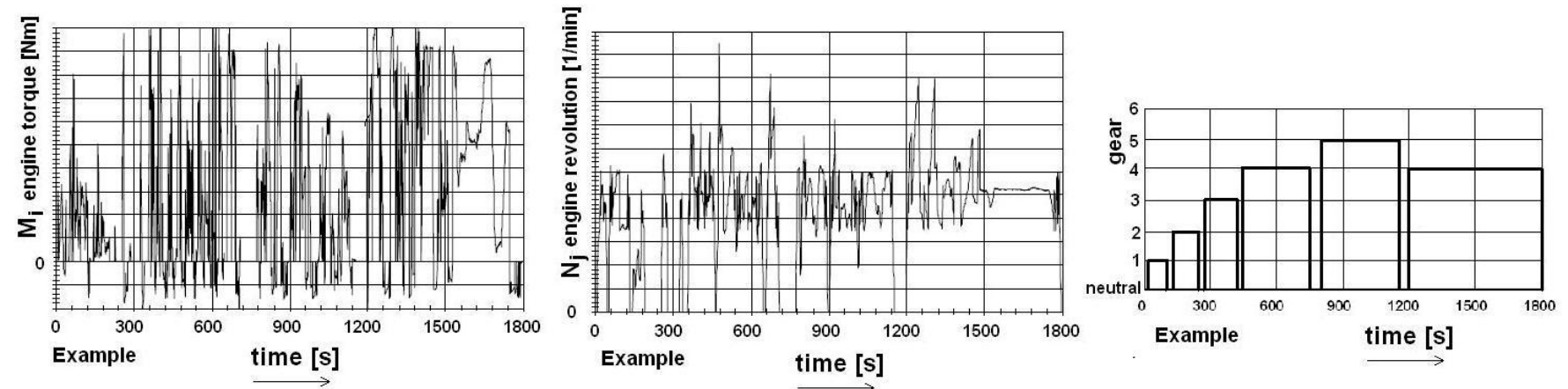

FIGURE 1: Torque, revolutions and gear changing during car operation.

OBRÁZEK 1: Průběh momentu, otáček a řazení převodových stupňů během jízdy 


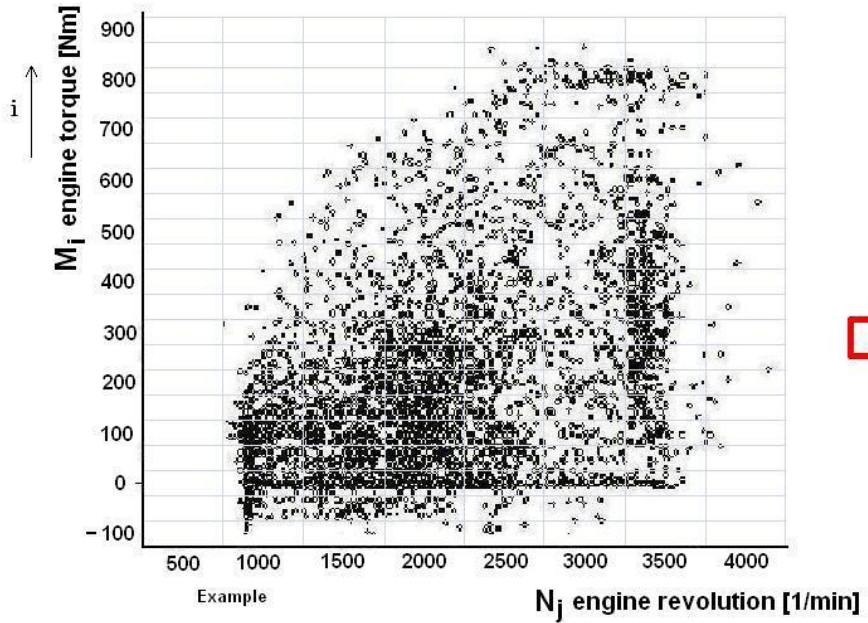

$\stackrel{j}{\longrightarrow}$

engine load map

scaled into torque and revolution levels
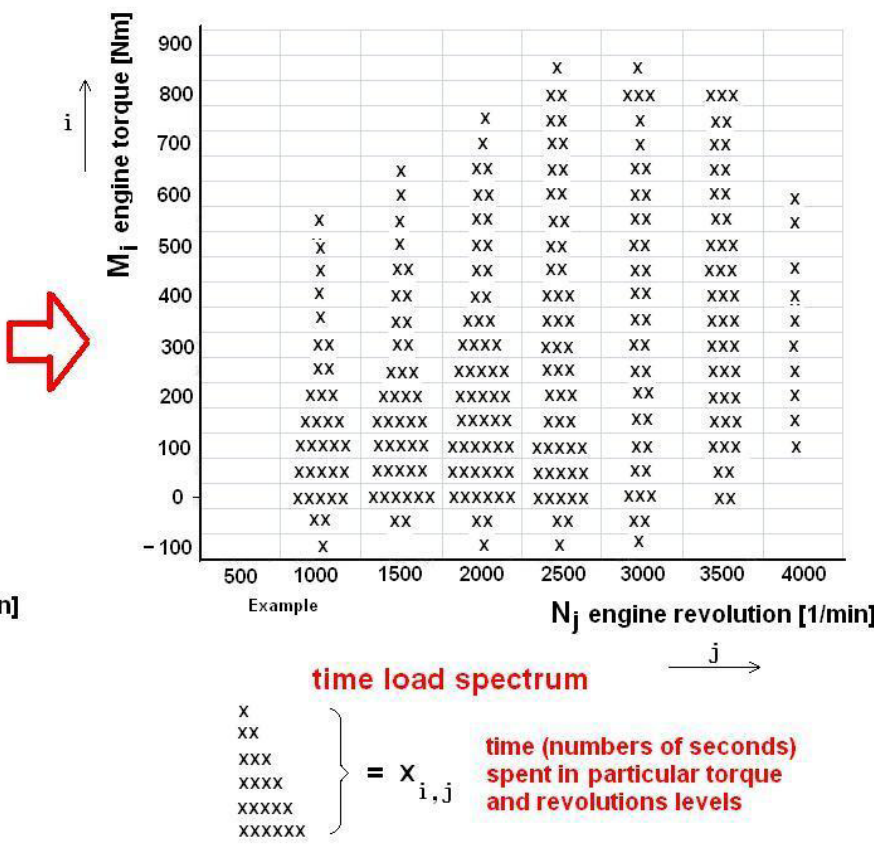

FIGURE 2: An engine load map and its transformation into a time load spectrum.

OBRÁZEK 2: Mapa zatížení motoru a její transformace na časové spektrum zatížení

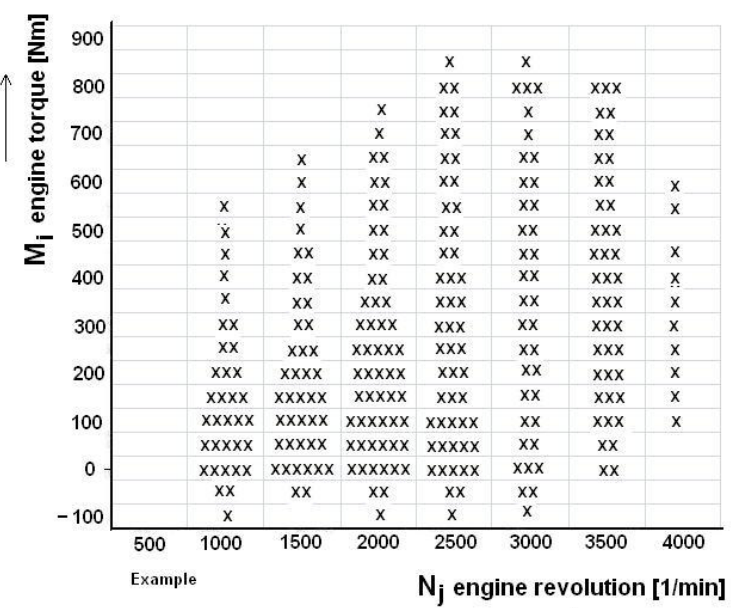

time load spectrum

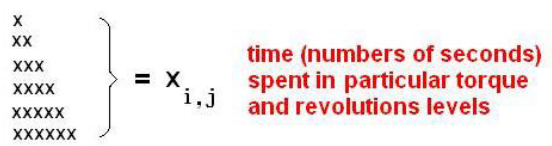

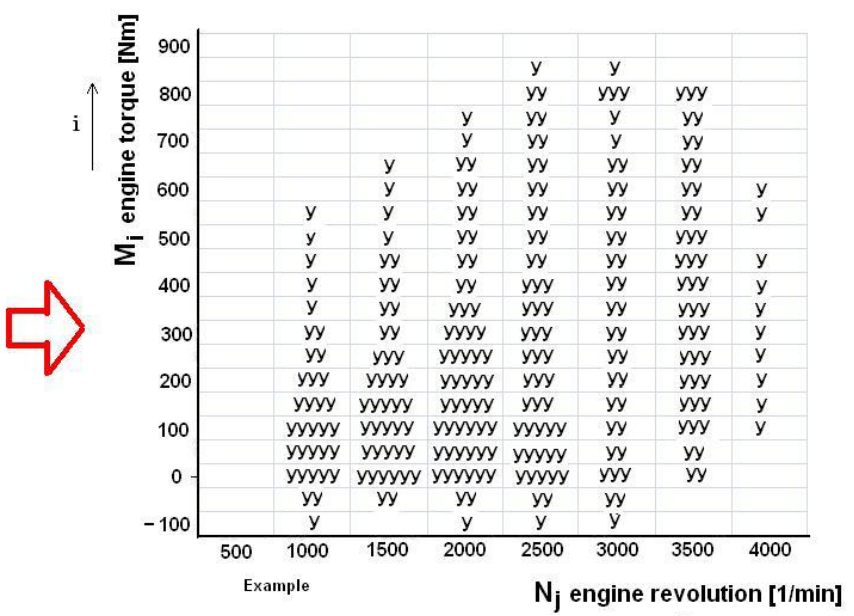

load spectrum (in cycles)

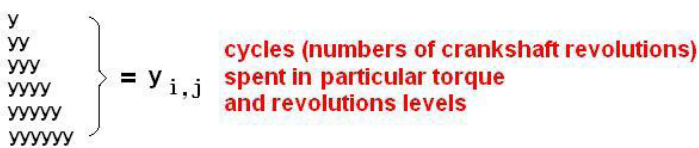

FIGURE 3: An engine load spectrum $y_{i, j}$ (in cycles).

OBRÁZEK 3: Spektrum zatížení motoru $\mathrm{y}_{\mathrm{i}, \mathrm{j}}$ ( $\mathrm{v}$ cyklech)

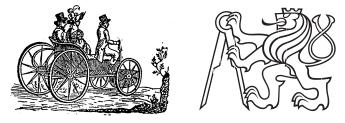



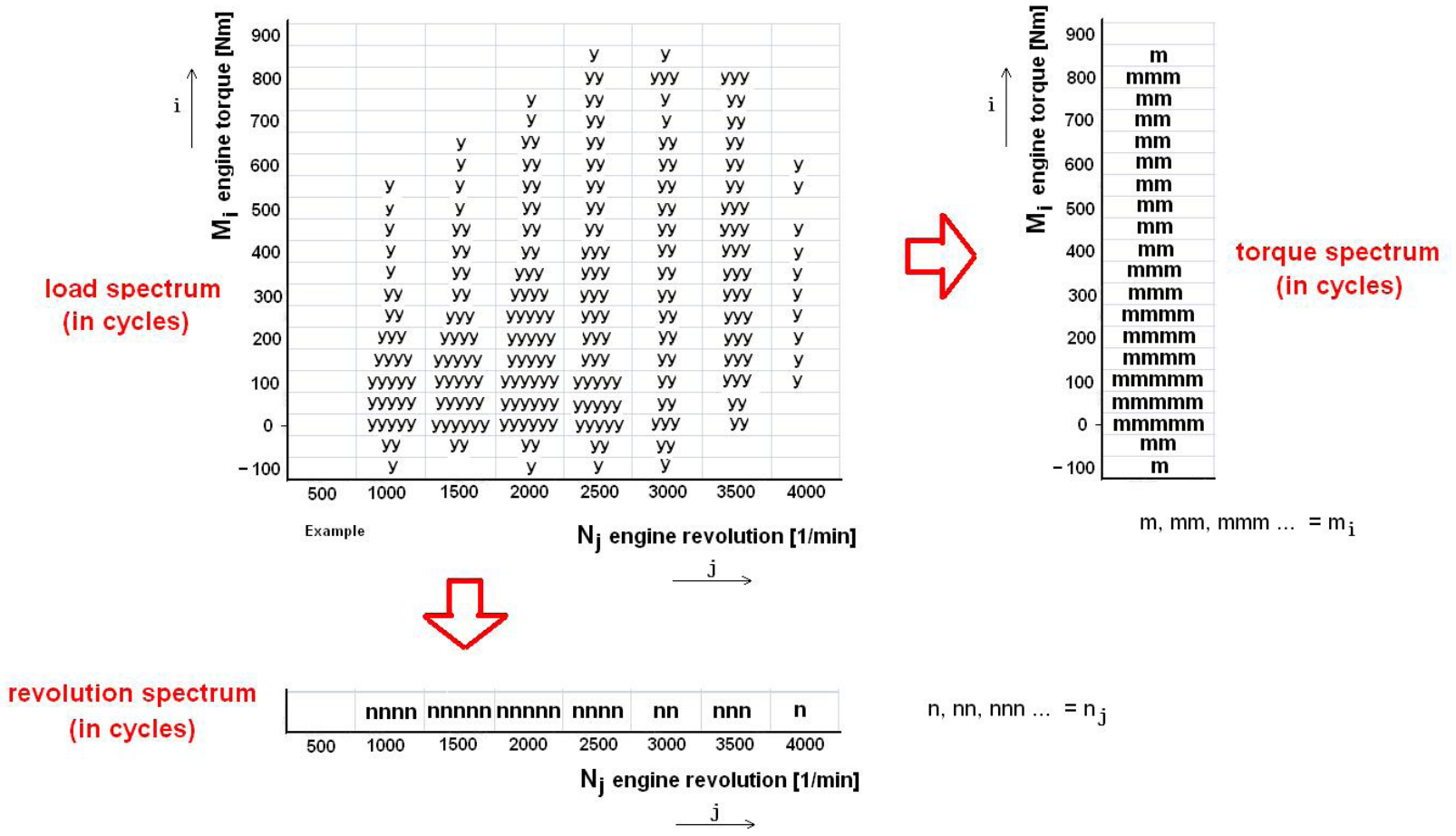

FIGURE 4: A two-dimensional and one-dimensional load spectrum (in cycles)

OBRÁZEK 4: Dvou-dimenzionální a jedno-dimenzionální spektrum (v cyklech)

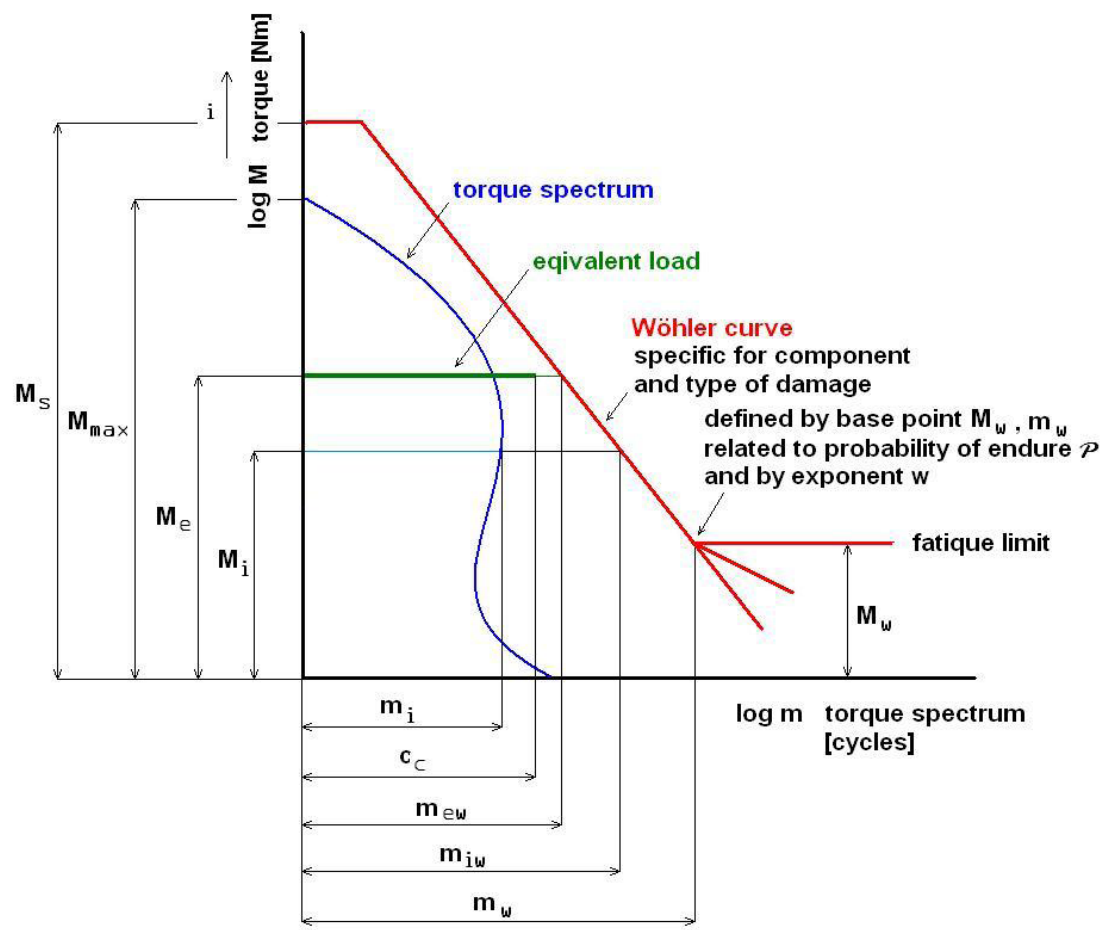

FIGURE 5: The equivalent torque

OBRÁZEK 5: Ekvivalentní moment 
By digitization of torque and revolutions plots using a regular interval, e.g. 1 second, and by plotting these values as points on a torque-revolutions graph we can obtain an engine load map. A typical load map is shown on the left side of Figure 2.

The load map must be scaled into torque and revolutions levels. The number of points in every cell on levels $i$ (torque) and $j$ (revolutions) represents the time spent in this cell. Setting these numbers in a table with the same scaling as the engine load map gives us the time load spectrum, see Figure 2 .

The total time $T$ of car operation corresponding to total travelled distance $L$ is

$T=\sum_{i} \sum_{j} x_{i, j}[\mathrm{~s}]$

Where is $x_{i, j}$ the time spent in the cell $i, j$.

Comparing the time spectrum with the fuel consumption map or emissions map of the engine enables us to obtain a (static) prediction of fuel consumption or emissions.

Multiplying time values $x_{i, j}$ by column nominal values of revolutions $N_{j}$ we can obtain the load spectrum in cycles (numbers of revolutions) $y_{i, j}$ see Figure 3 .

$y_{i, j}=\frac{x_{i, j}}{60} \cdot N_{j}$

and the total number of cycles is

$c_{c}=\sum_{i} \sum_{j} y_{i, j}$

This load spectrum in cycles forms the basis for life and stress calculations.

\subsection{SPECTRUM FOR PARTICULAR GEAR STEPS}

For life and stress calculations of gearbox components (gears, bearings etc.) it is necessary to know the load spectrum separately for every gear step $g$. According to the record of active gearbox gears - see Figure 1 - the torque and revolutions records can be divided into separated records for every gear $g$ and transformed to the load spectrum in the same way as the complete spectrum. There will be a remainder of the complete spectrum, representing neutral or open clutch.

Time parts $T_{g}$ and numbers of cycles $c_{g}$ for particular gears can be obtained in a similar way to (1) and (3). Then the relative time utilization of particular gears are
$\tau_{g}=\frac{T_{g}}{T} ; \quad \sum_{g} \tau_{g}+\tau_{\text {neutral }}=1$

and the relative mean revolutions of particular gears are

$v_{g}=\frac{N_{\text {mean }}}{N_{P}} ; \quad N_{\text {mean } g}=\frac{\sum_{j}\left(N_{j} \cdot \sum_{i} x_{i, j}\right)}{T_{g}} ;$

Where $N_{p}$ are nominal revolutions (revolutions at maximum engine power).

The relative distance utilization of particular gears

$\lambda_{g}=\frac{L_{g}}{L} ; \quad \sum_{g} \lambda_{g}+\lambda_{\text {neutral }}=1 ;$

can be directly measured or calculated from equation (7):

$\lambda_{g}=\frac{\frac{\tau_{g} \cdot v_{g}}{g_{c g} \cdot}}{\sum_{g}\left(\frac{\tau_{g} \cdot v g}{g_{c g}}\right)} ;$

Where $g_{c g}=$ gear ratio between the engine and wheels of a vehicle for particular gear $g$.

\subsection{ONE-DIMENSIONAL SPECTRUM}

A one-dimensional spectrum is often used in practical calculations. A torque spectrum $m_{i}$ can be obtained from a twodimensional load spectrum as a sum of values in the rows, see (8). Similarly, a revolutions spectrum $n_{j}$ can be derived as a sum of values in the columns, see (9) and Figure 4. Also a combination of torque spectrum and mean revolutions according to equation (5) is often applied in service life calculations.

Values (numbers of cycles) of a torque spectrum are

$$
m_{i}=\sum_{j} y_{i, j}
$$

and values of a revolutions spectrum are

$$
n_{j}=\sum_{i} y_{i, j}
$$

\subsection{EQUIVALENT LOAD}

In some cases we need to know only one-level load with the same influence on a component as the whole spectrum. For this purpose we must work with a Wöhler curve, defined by a base point related to probability of survival and an exponent (slope of the curve in logarithmic coordinates). We can define the intensity of damage $D$ on each level $i$ of the original torque spectrum 


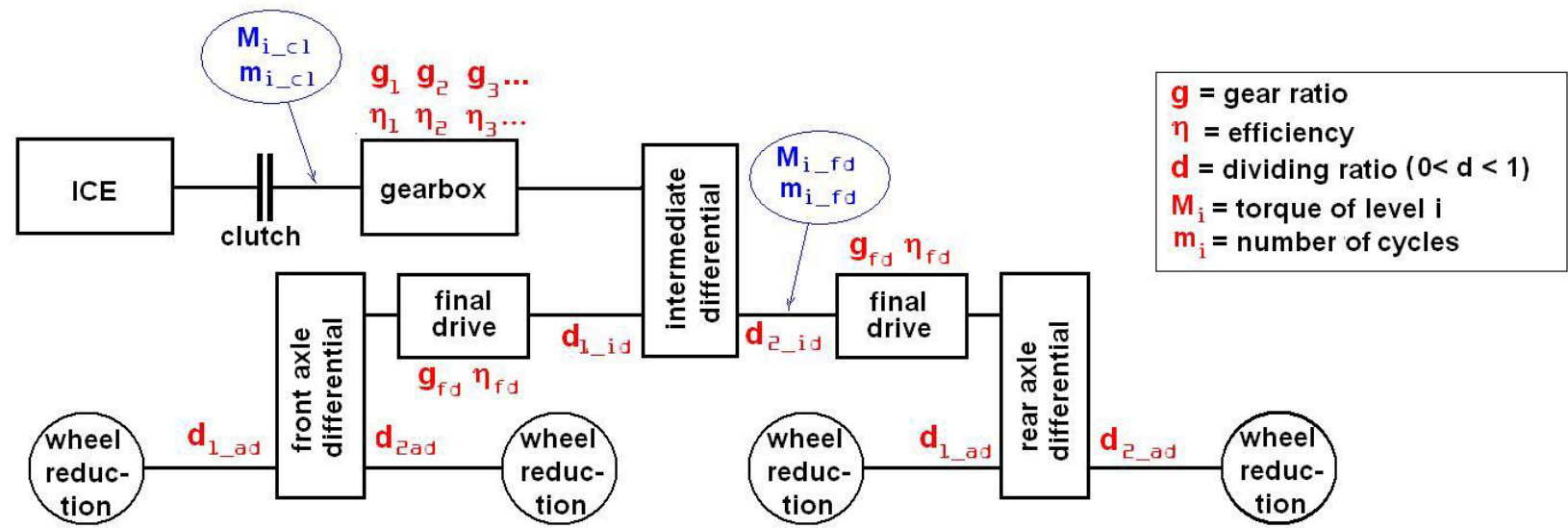

FIGURE 6: Transformation of load spectrum to another shaft of the powertrain OBRÁZEK 6: Transformace spektra zatížení na jiný hř́del hnacího ústrojí

\section{Examples:}

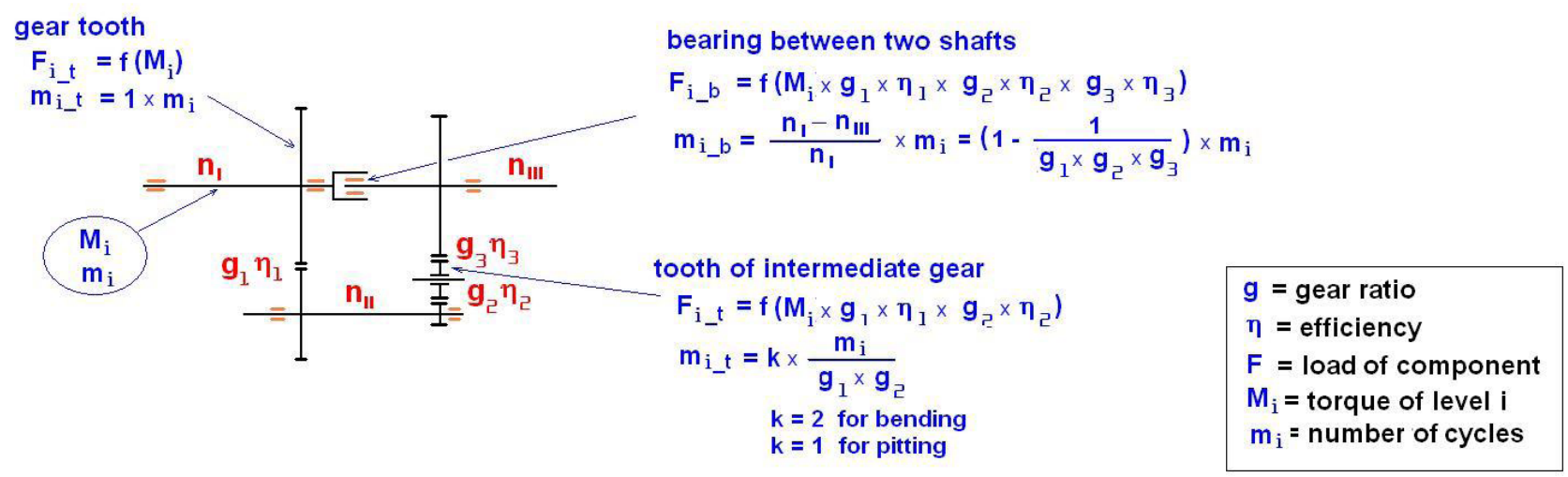

FIGURE 7: Examples of load spectrum transformation to a component

OBRÁZEK 7: Příklady transformace spektra zatížení na součástku

$D_{i}=\frac{m_{i}}{m_{i w}}$

Where $m_{i w}$ is the number of cycles corresponding to the Wöhler curve on level $i$.

Then we look for such equivalent level $e$ that meets the condition

$$
D_{e}=\frac{c_{c}}{m_{e w}}=\sum_{i} D_{i}
$$

where

$c_{c}=\sum_{i} m_{i}$

for a complete or particular spectrum.

Then the equivalent torque is

$M_{e}=\sqrt[w]{\frac{\sum_{i}\left(M_{i}^{w} \cdot m_{i}\right)}{c_{c}}}$ [N.m ]

Where $M_{i}$ is torque corresponding to level $i$.

Then the relative equivalent torque is 
$\mu_{e}=\frac{M_{e}}{M_{M}}$

and relative top torque coefficient

$\zeta=\frac{M_{\max }}{M_{M}}$

where $M_{M}$ is nominal torque (maximum engine torque).

Because the Wöhler curve is different for each sort of component and type of damage, the equivalent torque will also be different for each such case.

The top load should be checked by static safety

$S_{S}=\frac{M_{S}}{M_{\max }}$

Where Ms is permissible static load.

The aggressiveness of a spectrum can be expressed by a degree of aggressiveness [2]

$S_{k}=\frac{\log \left[\frac{\log \left(m_{k_{-} \text {cum }} / c_{c}\right)}{\log \left(m_{1} / c_{c}\right)}\right]}{\log \left(\frac{M_{k}}{M_{1}}\right)}$

where numbers of cycles of cumulative spectrum are (for $k$ from the top down, index 1 is top level)

$m_{k_{-} \text {cum }}=m_{(k-1) \_c u m}+m_{k}$

Then the degree of aggressiveness $s$ is the average value of $s_{k}$. The higher degree of $s$, the greater the influence of high levels of the torque spectrum.

\subsection{TRANSFORMATION OF LOAD TO ANOTHER SHAFT OF THE POWERTRAIN}

The engine load spectrum is usually defined on the output shaft of the clutch, i.e. also including the influence of the clutch. However, for stress and life calculations we need to know the load spectrum on the input shaft of a checked powertrain unit (gearbox, final drive etc.). The transformation can be performed using the respective gear ratios $g$, efficiencies $\eta$ and dividing ratios $d$ of differentials $(0<\mathrm{d}<1)$, if they exist.

An example: Transformation of torque spectrum of the $1^{\text {st }}$ gear from the output shaft of the clutch to the input shaft of the rear axle final drive (see Figure 6):

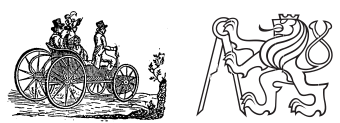

$M_{i_{-} f d}=M_{i_{-} c l} \cdot g_{1} \cdot \eta_{1} \cdot d_{2_{-} i d}[\mathrm{~N} . \mathrm{m}]$

$m_{i_{-} f d}=\frac{m_{i_{i} c l}}{g_{1}}[$ cycles $]$

If the load spectrum is known (measured) on another shaft of the powertrain, it can be transformed into the output shaft of the clutch (or another shaft) using equations (19) and (20) in reversed form.

\subsection{TRANSFORMATION OF A LOAD SPECTRUM TO}

\section{A COMPONENT}

There is no general rule for transformation of a load spectrum from an input shaft of a unit to a unit component (gear tooth, bearing etc.). It depends on the type of component, its position in the unit and the type of damage. It is necessary to solve every case individually. Figure 7 shows some examples $\left(F_{i}\right.$ is a load of a component corresponding to torque $M_{i}$ ).

\section{HOW TO OBTAIN THE LOAD SPECTRUM}

There are several methods for obtaining a load spectrum. Generally, direct measuring of a car powertrain load on a real road, computer simulation of car drive or a simplified calculation can be used.

\subsection{DIRECT MEASURING}

The engine torque and revolutions or torque and revolutions on another shaft of the powertrain (e.g. on the axle [1]) have to be measured during car operation, see Figure 1. An indirect method of torque measurement [2] can also be used. Parallel to this, the selected gearbox gear, clutch position and other information (time, travelled distance, speed, GPS coordinates, altitude etc.) should be recorded. Coordination of all records is very important.

Measured values should be treated using the process described in chapter 2.

\subsubsection{ADVANTAGES AND DISADVANTAGES OF DIRECT LOAD MEASUREMENT}

The measurement is performed on a real car whilst being driven on a road. This is the only method for obtaining the real spectrum!

On the other hand, there are some problems. Firstly, we need a car. This method can't be applied during the stage of car design. Secondly, we must choose a typical road. Moreover, there are influences from traffic density, driver's style of driving 

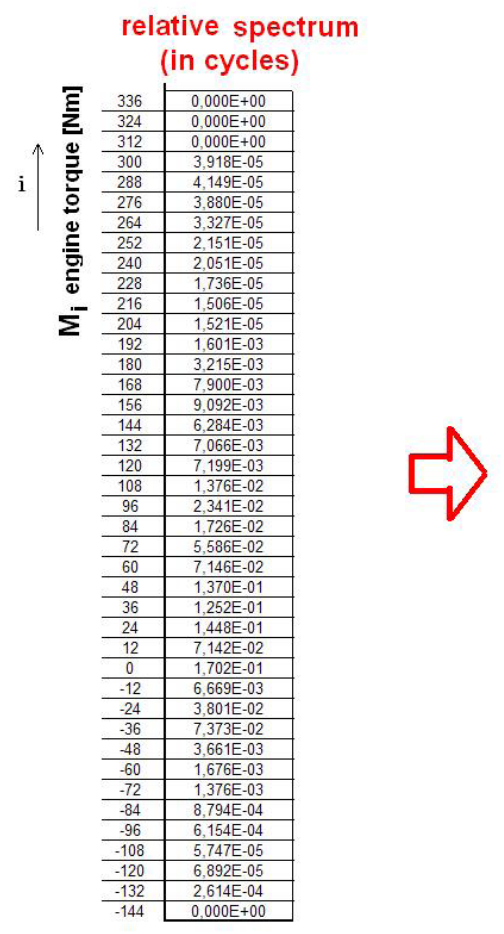

FIGURE 8: Relative and cumulative spectrum OBRÁZEK 8: Relativní a kumulativní spektrum

etc. Therefore the measurement must be performed on a few different roads with several drivers, and it is relatively expensive.

This method is necessary for the validation of the other methods.

\subsection{COMPUTER SIMULATION OF CAR DRIVE}

The second method for obtaining the load spectrum is computer simulation of a car drive, e.g. using the computer program DRIVE ("JíZDA") [3], [4]. This program is based on the solution of a system of equations at every step of a drive. At each step the drive situation (engine torque, revolutions, active gear in the gearbox, speed etc.), road parameters (length of step, high-altitude and speed profile, curves), driver's requirements (continue, accelerate,...), car weight and other information are known. Optimization parameters "price of time" and "price of fuel" are used for simulation of the driver's behavior. A real road or a test cycle or another type of track can be used for a drive simulation.

There are several types of results:

- detailed results for step-to-step of calculation

- fuel consumption at every step, and total

- two-dimensional and one-dimensional torque and revolutions spectra in \% and torque spectrum in cycles

- relative time and distance utilizations, relative mean revolutions, relative equivalent torque for more exponents of the Wöhler curve, relative top torque coefficient

- numbers of gear changes

which all apply to both particular gears, and the complete spectrum.

Additionally, speed, acceleration, efficiency and road slope spectra, total time and distance and average speed are presented.

\subsubsection{ADVANTAGES AND DISADVANTAGES OF THE COMPUTER SIMULATION}

The main advantages are sufficiently accurate calculation results, the ability to simulate driver behavior, the ability to change car mass during a drive and an acceptable calculation time.

The data preparation is rather time consuming. The full engine characteristic including specific fuel consumption is required. Also a detailed description of the road (high-altitude and speed profile) must be known. The influence of traffic density is not included.

This method is particularly suitable in the car development stage. 


\subsection{SIMPLIFIED CALCULATION OF THE LOAD SPECTRUM}

This calculation is based on empirical formulas, derived from generalized results of load measurement [5] and performed using the computer program FS SPEKT [6] for a variable powertrain arrangement. There are a maximum of 6 symbolic tracks from highway to terrain, or their combinations that can be used for commercial vehicles and a maximum of 4 symbolic tracks from highway to urban operation or their combinations which can be used for personal cars.

Calculation results are as follows

- one-dimensional torque spectrum in $\%$ and in cycles

- relative time and distance utilizations, relative mean revolutions, relative equivalent torque for more exponents of the Wöhler curve, relative top torque coefficient

- number of gear changes

which all apply to both particular gears and the complete spectrum.

Total time and distance and average speed are also presented.

\subsubsection{ADVANTAGES AND DISADVANTAGES OF THE}

\section{SIMPLIFIED CALCULATION}

Only simple basic data of the car need to be known; there is no need for detailed descriptions. Calculation time is very short, and it is a simple matter to change car data and operating conditions (symbolic tracks).

Only the torque spectrum is calculated (not the two-dimensional spectrum). Calculation of negative torque (engine braking), driver behavior and traffic density are not included. Parts of the journey where the car is braking (by engine or brakes) or neutral is engaged can be taken into consideration by an empirical coefficient.

This method is suitable for the very early design stage and for fast checking of different powertrain variants.

\section{GRAPHIC REPRESENTATION}

A relative form of spectrum is usually used for graphic representation.

The relative spectrum can be obtained from a torque spectrum by transformation of the numbers of cycles to relative values

$m_{i \_r e l}=\frac{m_{i}}{c_{c}}$

and numbers of cycles of cumulative spectrum in relative form are (for $k$ from the top down): $m_{k_{-} \text {cum_rel }}=m_{(k-1) \_c u m_{-} r e l}+m_{k_{-} r e l}$

Relative and cumulative values for the spectrum in seconds can be similarly obtained.

An example of a real spectrum [1] is shown in Figure 8:

\section{CONCLUSION}

The various methods mentioned above are generally suitable in different phases of car design and development. It is important to know their advantages and weak point as well as the limitations of their use. To obtain the right relationships, spectra gained using the above-mentioned method are currently being compared as part of bachelor and diploma works at the Faculty of Mechanical Engineering of the Czech Technical University in Prague.

\section{ACKNOWLEDGEMENTS}

This research has been realized using the support of EU Regional Development Fund in OP R\&D for Innovations (OP VaVpl) and Ministry for Education, Czech Republic, project \# CZ.1.05/2.1.00/03.0125 - ED2.1.00/03.0125 Josef Božek Research Centre for Vehicles of Sustainable Mobility.

This support is gratefully acknowledged.

\section{REFERENCES}

[1] Folta Z., Hrudičková M. (2010). Metodika vyhodnocování zátěžných spekter převodovky osobního automobilu za různých jízdních podmínek. Zpráva D31 - VCJB 21E403_2010

[2] Moravec V., Dejl Z., Němeček M., Folta Z., Havlík J. (2009). Čelní ozubená kola v převodovkách automobilů. VŠB-TU Ostrava

[3] Opička F. (1988). Modelování jízdy sólo vozidla po trati (uživatelský návod - revize k 1.10.1988). Zpráva ÚVMV Z-52/88

[4] Baněček J. (2010). Vstupní data pro program SJIZDA. Zpráva VCJB

[5] Morkus J. (2011). Smluvní výpočet využití prevodových stupňů a spekter zatížení. Zpráva ČVUT-FS Z 11-14 